\title{
A note from the President
}

\author{
José J. G. Moura
}

(C) SBIC 2011

\section{The Society of \\ Biological Inorganic Chemistry}

SBIC has been established as a learned society of advanced research and education in the field of Biological Inorganic Chemistry

\section{SBIC COUNCIL}

\section{President}

José Moura, Lisbon, Portugal

Past President

Robert A. Scott, Athens, GA, USA

Secretary

Charles Riordan, Newark, DE, USA

\section{Treasurer}

Graeme Hanson, St. Lucia, Australia

\author{
Members \\ Victoria A. DeRose, Berkeley, CA, USA \\ Julia A. Kovacs, Seattle, WA, USA \\ Janet R. Morrow, Amherst, NY, USA \\ Stephen W. Ragsdale, Ann Arbor, MI, USA \\ Britt-Marie Sjöberg, Stockholm, Sweden \\ Paola Turano, Florence, Italy \\ Alejandro J. Vila, Rosario, Argentina
}

\author{
Chief Editor of JBIC \\ Lawrence Que Jr., Minneapolis, MN, USA \\ Program Committee/ICBIC-IOC \\ Kenneth D. Karlin, Baltimore, MD, USA \\ Nominations Committe \\ Lucia Banci, Florence, Italy \\ SBIC Website: \\ http://SBIChem.org
}

In August of 2011, celebrating the International Year of Chemistry, the forthcoming ICBIC15 will be hosted in Vancouver, playing an important role in convening the biggest crowd ever to discuss the topic of metal ions in biological sciences. Under the auspices of SBIC, complex problems in this field will be discussed in a unique multidisciplinary way that is of worldwide interest. As an example, our colleagues from Spain are carrying out a number of initiatives in this research area in 2011 and extending to 2012. The Bioinorganic Spanish Group met recently in Aguilas (Murcia), and by the end of the year Barcelona will host the 11th International Symposium in Applied Bioinorganic Chemistry (ISABC). In addition, Granada will organize the EUROBIC11 next year, and the 40th International Conference in Coordination Chemistry
(ICCC) will be held in Valencia in 2012. The visibility of these activities has important consequences for make the community come alive, attracting new members.

Also, the ability to teach students interested in metal in biology is more and more necessary in order to increase the implementation of this expertise in the private sector and to garner the interest and recognition of the general public and opinion makers/media about our community's ongoing contributions to science. The SBIC (through its members) performs a crucial service, and we must be increasingly inventive in terms of launching new programs and activities for training as well as diffusing knowledge and competencies in bioinorganic chemistry related sciences.

We hope to see you all in Vancouver. 